Geologische Rundschau 76/3 | 949-950 | Stuttgart 1987

\title{
The Upper Paleozoic pebbly mudstone facies of peninsular Thailand and western Malaysia - Continental margin deposits of Paleoeurasia - Reply.
}

\author{
By Wladyslaw Altermann, Berlin*)
}

I am sorry that $\mathrm{I} »$ missed the point « in some of my remarks on STAUFFERS and LEEs (1984) evidences for glacial origin of the pebbly mudstones. I hope to correct it in the following reply.

In the paper on the pebbly mudstone deposits of Thailand and Malaysia (Geol. Rdsch. 75/2, 371-381) I tried to show that the circumstantial evidence for the glaciomarine origin of these sediments is misconstrued and all the "hints « do not necessarily support the glaciomarine origin. I have also listed some points which indicate a non glacial origin of the pebbly mudstones. Although I was unable to completely exclude the possibility of glacial influence on these sediments (the arguments used were always negative), the important point is that in STAUFFERS and Lees discussion they were not able to give any positive arguments which would definately evidence for glaciomarine origin.

My detailed replies to STAuffers and LeEs comments are listed below:

1. I agree that the time range and the thickness of the pebbly mudstones are not well known, but this does not allow us to estimate these measurements to fit our preferred theories. The time range of Early/ Middle Devonian to Early/Middle Carboniferous (Burton, 1983) or the whole of the Carboniferous (TANTIWANIT, et al. 1983) has been discussed on the basis of regional arguments and fossil data. МrтсHELL et al. (1970) have found rugose coral and the trilobite Cyrtoymbole (Waribole) perlisensis in their facies $» \mathrm{D}$ « (pebbly mudstones) and estimated this fauna to be Late Devonian. To date, no other age has been proven for the pebbly mudstones. The »presence of a major disconformity with a large time gap" of course can not be ruled out, but no evidence is found in the field.

Bunopas \& VelLa (1984) are the workers who identified Australia as the Late Paleozoic »neighbor« of the Shan Thai Craton. Burret \& STAIT (1984) proposed a similar position for the Early Paleozoic.

\footnotetext{
*) Author's address: W. Altermann, Freie Universität Berlin, Institut für Angewandte Geologie, Wichernstraße 16, D-1000 Berlin 33.
}

Wherever the position of the $»$ Shan Thai Craton $*$ was, the time span of $40-75 \mathrm{~m}$. y. is too long for the depositon of glaciomarine dropstones.

2 . The character of megaclasts can only be discussed after extensive and statistically representative studies.

3. The evidence of deposition in relatively deep water in the Phuket area is given by the occurrence of turbiditic layers. Here, of course no record of grounded ice can be expected. On Langkawi Island and in the Kaeng Krachan area the situation is different. In the marginal marine to tidal flat deposits (LEE pers. comm., Pulau Ular) and in areas where strand placers (TANTIWANIT pers. comm., Kaeng Krachan area) were deposited, fossil moraines, striated boulders and roches moutonnees or other glacial structures should be common.

4. Of course the »Early Permian cool water fauna « from Phuket and Ko Phi Phi is »contemporaneous with the Asselian glacial deposits of Gondwana (WATERHOUSE 1982) but the conclusions of WATERHOUSE (1982) paper are unequivocal. Besides this, Grant (1976) examined the brachiopod fauna from the Rat Buri limestone (Sakmarian to Kazanian) which covers the pebbly mudstones. His analysis shows that these brachiopods lived under tropical conditions.

If the Permian coral found by Fontaine (1984) in Sumatra is from a different tectonic block, where is the suture connecting this block with the rest of Sumatra? The Walchia piniformis Schlotherm flora from the Trang coast area in Thailand (Bunopas \& VeLLA 1984) evidences euramerican provenance of this part of SE Asia.

5. No diamonds were found in the pebbly mudstones. If they were dropstones from icebergs into the marine mud how strong were they concentrated in the ice and in the pebbly mudstone to form a placer, after being reworked and resedimented on at least third deposit. Many of the diamondiferous kimberlite pipes on former Gondwanaland and Eurasia are younger than Paleozoic. Whichever is correct, the occurrence of diamonds in the pebbly mudstones would neither prove their glaciomarine 
origin nor the Gondwana provenance of these sediments.

I agree with STAUfFER \& LEE that the model drawn in my figure 5. is highly speculative. It is called »speculative interpretation «. Using the paleomagnetic results of BuNOPAS \& VELIA (1980) against this model it should also be mentioned that these authors claim a clockwise rotation of more than 180 degrees for the Shan Thai Craton, while crossing the Paleotethys. For the Carboniferous position, a paleolatitude of 13 degrees $S$ and for the Permian 19 degrees
$S$ are given (Bunopas 1981). In this case we should also find glaciomarine sediments on the present eastern edge of this craton. The paleomagnetic results by Mc ElHinny et al. (1974) give the Paleozoic position of the Malay Peninsula a paleolatitude of 15 degrees N.

All the »evidences « for the glaciomarine origin of the pebbly mudstones are too poor to call the strata definately glaciomarine. Judging from circumstantial speculations is attractive but unreliable. Circumstantial evidence is good but direct evidence is better.

\section{References}

References already cited in Altermann, Geol. Rdsch. $75 / 2,371-381$ and in Stauffers \& LeEs discussion are not repeated in the list below.

Bunopas, S. (1981): Paleogeographic history of western Thailand and adjacent parts of Southeast Asia: A plate tectonic interpretation. - Geol. Surv. Paper No.: 5, spec. issue, Geol. Surv. Dev., DMR, Bangkok, Thailand, 810 pp.

Burton, C. K. (1983): Stratigraphy and correlation of the Middle to Late Paleozoic in peninsular Thailand. - Proc. Workshop Strat. Correl. Thailand and Malaysia., 2, Had Yai, Thailand, Sept. 1983.
Burret, C. \& Stait, B. (1984): Southeast Asia as a part of Early Paleozoic Gondwanaland. - GEOSEA V Proc. Vol.1, Geol. Soc. Malaysia Bull. 19, April 1986, 103-107.

Grant, R. E. (1976): Permian brachiopods from southern Thailand. - J. Paleont. 50, Part II of II, Suppl. to No.:3, The Paleont. Soc. Mem. 269pp.

Mc Elfinny, M. W., Haile, N. S. \& Crawford, A. R. (1974): Paleomagnetic evidence shows Malay Peninsula was not a part of Gondwanaland. - Nature, 252, Dec. $20 /$ $27,641-645$. 